\title{
Plasmapheresis in the Treatment of Acute Liver Failure: $A$ Case Report and a Review of the Literature
}

\author{
Akut Karaciğer Yetmezliğinin Tedavisinde Plazmaferez: Olgu Sunumu ve Literatür Incelemesi
}

\author{
Aslıhan CANDEVIR ULU1, Sedef KURAN2, Behice KURTARAN1, Ayşe SEZA INAL1, Süheyla KÖMÜR1, \\ Ferda TEKINTURHAN3, Birol GÜVENÇ2, Hasan Salih ZEKI AKSU1
}

${ }^{1}$ Çukurova University Faculty of Medicine, Department of Infectious Diseases and Clinical Microbiology, Adana, Turkey

2Çukurova University Faculty of Medicine, Department of General Medicine, Adana, Turkey

${ }^{3}$ Çukurova University Faculty of Medicine, Department of Apheresis, Adana, Turkey

\begin{abstract}
Acute liver failure (ALF) is a fatal and challenging disease even for patients without underlying diseases. In this paper, we aimed to share our opinion about a treatment option for cholestatic fulminant hepatitis where transplantation is not an option. A 36-year-old male with sickle-cell anemia (SCA) and G6PD deficiency presented with jaundice and fever. Alanine aminotransferase (ALT), aspartate aminotransferase (AST), total bilirubin, direct bilirubin and international normalized ratio (INR) levels were $335 \mathrm{mg} / \mathrm{dl}, 430$ $\mathrm{mg} / \mathrm{dl}, 30 \mathrm{mg} / \mathrm{dl}, 18 \mathrm{mg} / \mathrm{dl}$ and 1.2 , respectively at the admission. HBsAg was positive. Hepatitis B virus (HBV) DNA was 64.000 .000 $\mathrm{IU} / \mathrm{ml}$. On the third week of admission, ALT, AST, total bilirubin and direct bilirubin levels increased up to $270 \mathrm{mg} / \mathrm{dl}, 460 \mathrm{mg} / \mathrm{dl}, 71$ $\mathrm{mg} / \mathrm{dl}$ and $47 \mathrm{mg} / \mathrm{dl}$, respectively. INR prolongation accompanied. Hepatic encephalopathy developed. Entecavir $1 \times 1 \mathrm{mg}$ and fresh frozen plasma was started. The condition of the patient continued to deteriorate and, MELD score was 38. After two sessions of plasmapheresis, ALT, AST, total bilirubin, direct bilirubin and INR levels decreased to $30 \mathrm{mg} / \mathrm{dl}, 90 \mathrm{mg} / \mathrm{dl}, 9 \mathrm{mg} / \mathrm{dll}, 4 \mathrm{mg} / \mathrm{dl}, 1.2$, respectively. The patient was discharged eventually. Plasmapheresis can be thought as treatment for patients in whom liver transplantation is not an option or for patients pending transplantation.

Keywords: Acute liver failure, acute hepatitis B, cholestasis, sickle cell disease, plasmapheresis
\end{abstract}

\section{ÖZ}

Akut karaciğer yetmezliği (AKY) altta yatan hastalığı olmayan kişilerde bile oldukça zor yönetilen bir ölümcül durumdur. Bu olguda, transplantasyonun bir seçenek olmadığı kolestatik fulminant hepatit için tedavi önerisini paylaşmak istedik. Otuz altı yaşında orak hücreli anemisi (OHA) ve glukoz 6 fosfat eksikliği olan bir hasta sarlık ve ateş ile başvurdu. Yatış sırasında, alanin aminotransferaz (ALT), aspartat aminotransferaz (AST), total bilirubin, direk bilirubin ve INR seviyeleri $335 \mathrm{mg} / \mathrm{dl}, 430 \mathrm{mg} / \mathrm{dl}, 30 \mathrm{mg} / \mathrm{dl}, 18 \mathrm{mg} / \mathrm{dl}$ ve 1,2 idi. HBsAg pozitif ve HBV DNA 64.000.000 IU/ml idi. Üçüncü haftada ALT, AST, total bilirubin ve direk bilirubin seviyeleri yükselerek $270 \mathrm{mg} / \mathrm{dl}, 460 \mathrm{mg} / \mathrm{dl}$, $71 \mathrm{mg} / \mathrm{dl}$ ve $47 \mathrm{mg} / \mathrm{dl}$ oldu. Uluslararası normalleştirilmiş oran (UNO) uzaması eşlik etti ve ensefalopati gelişti. Entekavir $1 \times 1 \mathrm{mg}$ ve taze donmuş plazma tedavisi başlandı. Hasta kötüleşmeye devam etti ve MELD skoru 38 olarak hesaplandı. Iki kez plazmaferez uygulanması sonrasında ALT, AST, total bilirubin, direk bilirubin ve UNO seviyeleri $30 \mathrm{mg} / \mathrm{dl}, 90 \mathrm{mg} / \mathrm{dl}, 9$ mg/dl, 4 mg/dl, 1,2'ye düştü. Genel durumu düzelen hasta taburcu edildi. Karaciğer transplantasyonunun tedavi seçeneği olmadığı hastalarda veya transplantasyon beklenen durumlarda plazmaferez tedavide düşünülebilir.

Anahtar Kelimeler: Akut karaciğer yetmezliği, akut hepatit B, kolestaz, orak hücreli anemi, plazmaferez

\section{Introduction}

Sickle-cell anemia (SCA) is one of the most common hereditary hematologic diseases worldwide. Patients with SCA require multiple blood transfusions and, therefore, are at an increased risk for blood-transmitted infections such as hepatitis B virus infection (1). Hepatic dysfunction in adults with sickle-cell disease varies in character and severity from self-limited cholestasis to life-threatening acute liver failure (ALF) and cirrhosis and, it is mainly caused by sickle hepatic crisis. Asymptomatic patients commonly have underlying liver 
damage such as hepatomegaly and those caused by elevated liver enzyme levels (2).

With the underlying hepatic damage, acute hepatitis can be severe and patients might need liver transplantation because of ALF. It has been shown that spontaneous recovery from ALF is very unlikely if the patient develops hepatic encephalopathy of grade three or four (3). Extracorporeal liver support devices, such as hemodialysis and plasmapheresis-based systems or multipass albumin dialysis systems had been used successfully in some cases (4).

In this paper we present a SCA patient with hepatic failure caused by acute cholestatic hepatitis B in whom plasmapheresis was performed successfully because transplantation was not an option.

\section{Case}

A 36-year-old male patient presented to the emergency room with jaundice and fever. He had a history of SCA and glucose-6-phosphate dehydrogenase (G6PD) deficiency. He was previously admitted to infectious diseases inpatient clinic with a diagnosis of chronic osteomyelitis. In the previous admission, he was recommended to get hepatitis $B$ vaccine shot but he never got it. He had fever and urticarial lesions on admission. Abdominal ultrasound and computed tomography imaging revealed only hepatomegaly and no findings of biliary stenosis. At the admission, alanine aminotransferase (ALT), aspartate aminotransferase (AST), total bilirubin, direct bilirubin and international normalized ratio (INR) levels were $335 \mathrm{mg} / \mathrm{dl}$, $430 \mathrm{mg} / \mathrm{dl}, 30 \mathrm{mg} / \mathrm{dl}, 18 \mathrm{mg} / \mathrm{dl}$ and 1.2, respectively. Hepatitis B surface antigen was found to be positive while it was negative 9 months ago. Hepatitis B core IgM antibody was negative and HBV DNA was $64.000 .000 \mathrm{IU} / \mathrm{ml}$. At first, ALT, AST and bilirubin levels started to decrease but did not come down to normal levels. While he was hospitalized, the patient had nonspecific antibiotic treatment for his fever. After 3 weeks, ALT, AST, total bilirubin and direct bilirubin levels started to increase again up to $270 \mathrm{mg} / \mathrm{dl}, 460 \mathrm{mg} / \mathrm{dl}, 71 \mathrm{mg} / \mathrm{dl}$ and $47 \mathrm{mg} /$ $\mathrm{dl}$, respectively. This time INR prolongation accompanied and it increased to 9 (the laboratory findings are shown in Graphic 1 and 2). Hepatic encephalopathy developed and the patient was admitted to the intensive care unit (ICU). Entecavir (ETV) $1 \times 1$ $\mathrm{mg}$ and fresh frozen plasma treatment were started because the patient was progressing to ALF. The status of the patient continued to deteriorate despite the supportive treatment. Liver transplantation could not be planned considering the low survival rates of SCA patients, and plasmapheresis came up as an option. After plasmapheresis, total bilirubin, direct bilirubin and INR levels decreased to $140 \mathrm{mg} / \mathrm{dl}, 255 \mathrm{mg} / \mathrm{dl}, 24 \mathrm{mg} / \mathrm{dl}, 13$ $\mathrm{mg} / \mathrm{dl}$, and 4.6, respectively. The patient's general condition and consciousness improved. After a slight increase in parameters, plasmapheresis was performed again on the next day and ALT, AST, total bilirubin, direct bilirubin and INR levels continued to decrease to $30 \mathrm{mg} / \mathrm{dl}, 90 \mathrm{mg} / \mathrm{dl}, 9 \mathrm{mg} / \mathrm{dl}, 4 \mathrm{mg} / \mathrm{dl}$, and 1.2 , respectively. The patient was discharged from the ICU and followed for a week by the infectious diseases inpatient department. After the parameters continued to improve, the patient was discharged. After seven months of follow up, HBV
DNA became negative, bilirubin (total bilirubin: $3 \mathrm{mg} / \mathrm{dl}$, direct bilirubin: $1 \mathrm{mg} / \mathrm{dl}$ ) and aminotransferase (ALT: $20 \mathrm{mg} / \mathrm{dl}$, AST: $38 \mathrm{mg} / \mathrm{dll}$ ) levels continued to improve, and hepatitis B surface antibody became positive $(250 \mathrm{IU} / \mathrm{ml})$.

\section{Discussion}

Patients with sickle-cell disease suffer from a range of liver complications, such as vascular complications from the sickling process, iron overload, development of pigment gallstones and risk for viral hepatitis because of receiving multiple transfusions (5). In this paper, such patient with sickle-cell hepatopathy who had ALF after acute hepatitis B infection is discussed. In this case, there was an extreme hyperbilirubinemia and, therefore, liver transplantation was indicated (6). Although there are case reports of successful liver transplantation for sickle-cell disease, the experience is still limited (7). Nevertheless, the patient was not found to be eligible for transplantation by our transplantation team because of very low success rates in this group of patients. When transplantation was not an option, supportive and antiviral treatments were started.

Dao et al. (8) investigated nucleoside (tide) analogues (NA) in hepatitis B-related ALF. Multivariate analysis revealed that not using a NA (odds ratio (OR) $4.4,95 \% \mathrm{Cl} 1.1-18.1, \mathrm{p}=0.041$ ), hepatic coma grade I or II (OR 14.4, 95\% Cl 3.3-62.8, $\mathrm{p}<0.001$ ) and prothrombin time (PT) (OR 0.59, 95\% Cl 0.39-0.89, $\mathrm{p}=0.012$ ) were predictors of improved transplant-free survival. However, despite the lack of benefit, they recommended antiviral therapy for transplantation candidates in order to prevent recurrence after grafting. On the contrary, a study of 17

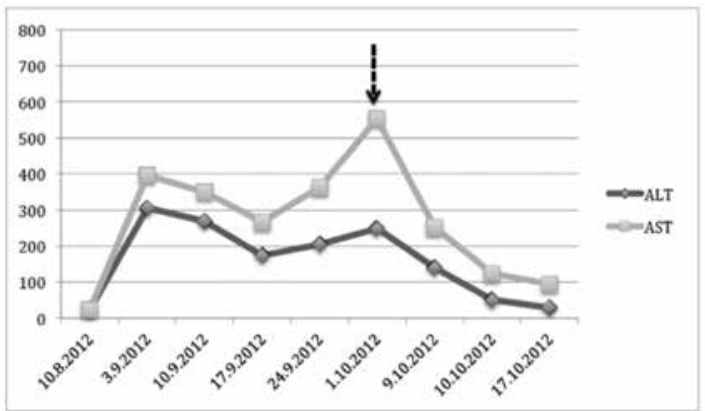

Graphic 1. Alanine aminotransferase and aspartate aminotransferase levels. Arrow shows the time of plasmapheresis

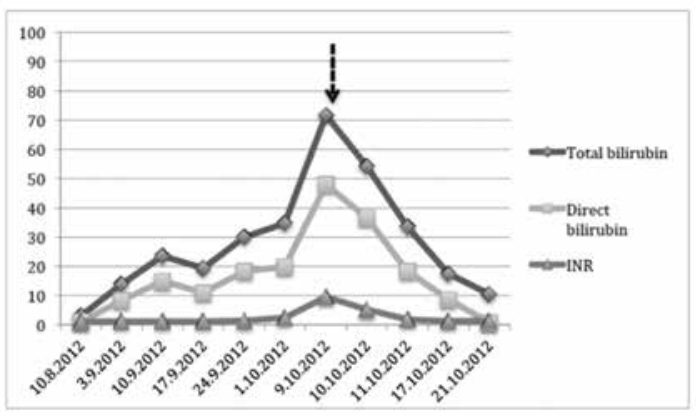

Graphic 2. Bilirubin and international normalized ratio levels. Arrow shows the time of plasmapheresis 
consecutive NA-treated patients with severe acute hepatitis B, when compared to historic controls, demonstrated significant improvement in overall survival. However, of the 7 patients who had hepatic encephalopathy, 6 patients had only hepatic coma grade I (9). Another study of severe acute hepatitis B suggested that treatment with lamivudine (LAM) yielded a positive clinical response in 13 of 15 patients. However, only 5 patients in this study had encephalopathy and there were no untreated controls (10). In a study by Chen et al., (11) among acute-on-chronic liver failure patients, the non-NAs group had a significantly high mortality rate, compared with the ETV group $(64.7 \%$ vs. $33.3 \%, p=0.007)$, the LAM group (64.7\% vs. $40 \%, p=0.042)$, and the NA group (ETV group+LAM group) (64.7\% vs. $36.2 \%$, $\mathrm{p}=0.006$ ). About antiviral therapy, practice guidelines and the recent consensus statement of an $\mathrm{NIH}$ panel on treatment of HBV infection have recommended NA for patients with HBVALF $(12,13)$. In our case, the patient did not improve after a short-term antiviral therapy; plasmapheresis came up as an option after encephalopathy developed and to clean the blood from toxic bilirubin. In a case of extreme hyperbilirubinemia caused by acute Epstein-Barr virus (EBV), plasmapheresis was initiated with corticosteroids that resulted in resolution of hyperbilirubinemia. Prednisone therapy has been used in several cases in the literature for EBV infection with hyperbilirubinemia but none of the cases had hyperbilirubinemia this serious (14). In our case, steroid treatment was not an option because of the risk of deterioration of hepatitis B. Singer et al. (15) investigated the role of plasmapheresis in the management of acute hepatic failure in children. Plasmapheresis was found as a useful technique in preventing complications such as coagulopathy in the setting of acute liver failure. It was not suggested as replacement for definitive therapy for the liver failure, which in most cases is liver transplantation. However, in the subpopulation with toxic injury, plasmapheresis may allow sufficient time for hepatocyte recovery and regeneration. In our case, hyperbilirubinemia resulted in more hepatic injury and caused higher bilirubin levels, which resulted in a vicious circle where bilirubin levels continued to increase. The reason for our case's being successful may be the injury mechanism's being similar with the toxic cases. Akdogan et al. (16) assessed the efficacy of total plasma exchange in fulminant hepatic failure in a group of patients of which $18 \%$ were with acute hepatitis B. As a result, coagulopathy, hyperbilirubinemia, and hyperammonemia were significantly improved $(p<0.05)$. Twenty-one patients survived (54\%) and ten patients did not undergo transplantation. The authors stated that this intervention could be considered for temporary liver support until recovery or liver transplantation. A retrospective Japanese study evaluated survival outcomes in 33 patients with ALF defined by the presence of encephalopathy and coagulopathy; 29 of $33(88 \%)$ patients underwent plasma exchange. In this report it has been observed that NA use was associated with significant survival benefits in 10 patients (17). As mentioned in a review by Bacher, (4) extracorporeal liver support by plasmapheresis or similar filtering systems like multipass albumin dialysis may increase the rate of spontaneous recovery and reduce the need for transplantation.
As a conclusion, despite not having an indication, plasmapheresis can be thought as a treatment for ALF patients particularly in those with cholestasis in whom liver transplantation is not an option such as SCA patients or the ones pending transplantation.

\section{Authorship Contributions}

Ethics Committee Approval: No ethics committee approval needed, Informed Consent: No informed consent needed, Concept: Aslıhan Candevir Ulu, Hasan Salih Zeki Aksu, Design: Aslıhan Candevir Ulu, Hasan Salih Zeki Aksu, Data Collection or Processing: Aslıhan Candevir Ulu, Sedef Kuran, Analysis or Interpretation: Aslıhan Candevir Ulu, Sedef Kuran, Literature Search: Aslıhan Candevir Ulu, Behice Kurtaran, Writing: Behice Kurtaran, Ayşe Seza Inal, Süheyla Kömür, Ferda Tekinturhan, Birol Güvenç, Hasan Salih Zeki Aksu, Peer-rewiev: External and Internal peer-reviewed, Conflict of Interest: No conflict of interest was declared, Financial Disclosure: he authors declared that this study has received no financial support.

\section{References}

1. Ocak S, Kaya H, Cetin M, Gali E, Ozturk M. Seroprevalence of hepatitis $B$ and hepatitis $C$ in patients with thalassemia and sickle cell anemia in a long-term follow-up. Arch Med Res. 2006;37(7):895-898.

2. Schubert TT. Hepatobiliary system in sickle cell disease. Gastroenterology. 1986;90(6):2013-2021.

3. Eisenhuber E, Madl C, Kramer L, Steininger R, Yeganehfar $W_{\text {, }}$ Ratheiser K, Gangl A. Prognostic factors in acute liver failure. Wien Klin Wochenschr. 1998;110(16):564-569.

4. Bacher A. Extracorporeal liver support with multipass albumin dialysis or plasmapheresis and filtering systems in acute liver failure. Liver Int. 2011;31 Suppl 3:16-18.

5. Banerjee S, Owen C, Chopra S. Sickle cell hepatopathy. Hepatology. 2001;33(5):1021-1028.

6. O'Leary JG, Lepe R, Davis GL. Indications for liver transplantation. Gastroenterology. 2008;134(6):1764-1776.

7. Blinder MA, Geng B, Lisker-Melman M, Crippin JS, Korenblat K, Chapman W, Shenoy S, Field JJ. Successful orthotopic liver transplantation in an adult patient with sickle cell disease and review of the literature. Hematol Rep. 2013;5(1):1-4.

8. Dao DY, Seremba E, Ajmera V, Sanders C, Hynan LS, Lee WM; Acute Liver Failure Study Group. Use of nucleoside (tide) analogues in patients with hepatitis B-related acute liver failure. Dig Dis Sci. 2012;57(5):1349-1357.

9. Tillmann HL, Hadem J, Leifeld L, Zachou K, Canbay A, Eisenbach C, Graziadei I, Encke J, Schmidt H, Vogel W, Schneider A, Spengler U, Gerken G, Dalekos GN, Wedemeyer $H$, Manns MP. Safety and efficacy of lamivudine in patients with severe acute or fulminant hepatitis $B$, a multicenter experience. J Viral Hepat. 2006;13(4):256-263.

10. Schmilovitz-Weiss $H$, Ben-Ari Z, Sikuler E, Zuckerman E, Sbeit W, Ackerman Z, Safadi R, Lurie Y, Rosner G, Tur-Kaspa R, Reshef R. Lamivudine treatment for acute severe hepatitis $B$ : a pilot study. Liver Int. 2004;24:547-551.

11. Chen T, He Y, Liu X, Yan Z, Wang K, Liu H, Zhang S, Zhao $Y$. Nucleoside analogues improve the short-term and long-term prognosis of patients with hepatitis B virus-related acute-onchronic liver failure. Clin Exp Med. 2012;12(3):159-164. 
12. Lok AS, McMahon BJ. Chronic hepatitis B: update 2009. Hepatology. 2009;50(3):661-662.

13. Sorrell MF, Belongia EA, Costa J, Gareen IF, Grem JL, Inadomi JM, Kern ER, McHugh JA, Petersen GM, Rein MF, Strader DB, Trotter HT. National Institutes of Health Consensus Development Conference Statement: management of hepatitis B. Ann Intern Med. 2009;150(2):104-110.

14. Place E, Wenzel JE, Arumugam R, Belani K, Messinger $Y$. Successful plasmapheresis for extreme hyperbilirubinemia caused by acute Epstein-Barr virus. J Pediatr Hematol Oncol. 2007;29(5):323-326.
15. Singer AL, Olthoff KM, Kim H, Rand E, Zamir G, Shaked A. Role of plasmapheresis in the management of acute hepatic failure in children. Ann Surg. 2001;234(3):418-424.

16. Akdogan M, Camci C, Gurakar A, Gilcher R, Alamian S, Wright $H$, Nour B, Sebastian A. The effect of total plasma exchange on fulminant hepatic failure. J Clin Apher. 2006;21(2):96-99.

17. Miyake Y, Iwasaki Y, Takaki A, Fujioka S, Takaguchi K, Ikeda $H$, Kobashi H, Sakaguchi K, Shiratori Y. Lamivudine treatment improves the prognosis of fulminant hepatitis B. Intern Med. 2008;47(14):1293-1299. 